\title{
Review of COVID-19 Re-Infection among Recovered Patients and Its Implication for Lung Health
}

\author{
Nkiru Edith Obande-Ogbuinya ${ }^{1}$, Lois Nnenna Omaka-Amari ${ }^{2}$, Jude N. Nwafor ${ }^{3}$, Chinenye B. Omeje ${ }^{3}$, \\ Maria-lauretta Chito Orji ${ }^{4}$, Chihurumnanya $\mathrm{Alo}^{5}$, Patricia C. $\mathrm{Ngwakwe}^{2}$, Onyechi Nwankwo ${ }^{6}$, Ifeyinwa Maureen \\ Okafor $^{6}$, Precious Ijeoma Igwenyi ${ }^{1} \&$ Christian Okechukwu Aleke ${ }^{2}$ \\ ${ }^{1}$ Science Education, Faculty of Education, Alex Ekwueme Federal University, Ndufu Alike, Ebonyi State Nigeria \\ ${ }^{2}$ Department of Human Kinetics and Health Education, Ebonyi State University, PMB 053 Abakaliki, Ebonyi \\ State, Nigeria \\ ${ }^{3}$ Department of Physical and Health Education, Ebonyi State University College of Education Ikwo, Nigeria \\ ${ }^{4}$ Department of Paediatrics, Alex-Ekwueme Federal University Teaching Hospital Abakaliki, Nigeria \\ ${ }^{5}$ Department of Community Medicine AE-FUTHA, Ebonyi State, Nigeria \\ ${ }^{6}$ African Institutes for Health Policy and Health Systems, Ebonyi State University, Nigeria
}

Correspondence: Christian Okechukwu Aleke, Department of Human Kinetics and Health Education, Faculty of Education, Ebonyi State University, PMB 053 Abakaliki, Nigeria Tel: 234-703-085-6506. E-mail: Christian.aleke2020@gmail.com; christian.aleke@yahoo.com

Received: August 7, 2020 Accepted: September 27, 2020 Online Published: October 19, 2020

doi:10.5539/gjhs.v12n12p64 URL: https://doi.org/10.5539/gjhs.v12n12p64

\begin{abstract}
COVID-19 infection has continued to pose a very serious health threat to mankind globally despite all efforts geared toward curbing its spread. More worrisome recently is the report from different parts of the world on the re-infection of those treated and recovered with COVID -19 patients thus making containment of the virus even more difficult. Of more worrisome is the fact that the lung, a vital human organ is a major site being attacked by the virus even on re-infection cases. If quick action is not taken early enough, it may lead to the outright death of the patient. A lung infection, (Pneumonia) caused by COVID-19 has been discovered to be having a stunning effect on hospital systems and killing COVID-19 patients silently and it occurs even as the patient is asymptomatic. This paper examines the reasons for re-infection, Lacuna in the reviewed literature with regards to PCR test results, the effect of re-infection on the lungs, and implication for patients' lung health. The papers summarized and concluded that it's a fact that re-infection occurs among patients accompanied by mild or severe symptoms having far-reaching implications for the patient's lung health. The paper recommends that the government at all levels should collaborate with $\mathrm{WHO}, \mathrm{CDC}$, and health policymakers to legally mandating, that every recovered patient should stay an additional 2 weeks in the hospital for early detection of re-infection in order to avert any invasion and damage to the lungs thus ensuring lung health. Also, proper health education should be availed to the recovered patients to avoid any exposures or habits (different from the index disease) such as smoking that can pose dangers to the already fatigued lungs.
\end{abstract}

Keywords: COVID-19 Pneumonia, Coronavirus re-infection, recovered patient, Lung Health

\section{Introduction}

The novel coronavirus disease 2019 (COVID-19) pandemic outbreak, which started in the Hubei province of China in December 2019, has become a major public health challenge for not only China but also countries around the world. The novel COVID-19 pandemic which is rapidly evolving has since spread to all continents in the world affecting over 210 countries. Since 31 December 2019 and as of $1^{\text {st }}$ May 2020, 3214256 cases of COVID-19 have been reported, including 232570 deaths and the number of reported cases is rapidly increasing worldwide (European Centre for Disease Prevention and Control 2020). The novel COVID-19 which is caused due to severe acute respiratory syndrome coronavirus-2 (SARS-CoV-2) has severe illness with high attack and case fatality rate around the globe (Balachandar et al., 2020).

The novel COVID-19 infection has continued to pose a very serious health threat to mankind globally despite all 
efforts geared toward curbing its spread and consequential high mortality. More worrisome recently is the report from different parts of the world on the re-infection of recovered patients (those who were infected with COVID -19 and got treated) thus making containment of the virus even more difficult (Stanway \& Kelland, 2020). More worrisome however, is the fact that the lung, which is the vital human organ is a major site being attacked by the novel virus even on re-infection cases. Studies have indicated that if quick action is not taken early enough, it may lead to the outright death of the patient (Stanway \& Kelland, 2020). There are indications that the pneumonia caused by the virus, COVID pneumonia was the major cause of deaths in COVID-19 patients. Hence, it causes much oxygen deprivation (hypoxia) and it is difficult to detect in nature (Levithan, 2020).

The COVID pneumonia (lung infection) does not present early even when the patient has been infected and yet to complain of breathing difficulty. The situation calls for worry globally, due cases of re-infection where patients assumed to have been treated of COVID-19 get hit once again from the virus. Studies have reported that over 163 recovered COVID-19 patients in Korea who on recovery tested positive once again as revealed by Korean Center for disease control (KCDC) (Hancocks, Seo, \& Hollingsworth, 2020). Another studies also observed patients who on seemingly recovery from COVID-19 tested positive to the virus, one hundred and eleven (111) of such cases were cited by South Korean Officials (Leung, 2020). Additional information on recovered COVID-19 patients in the Southern Chinese city of Shenzhen revealed that 38 out of $262(15 \%)$ of them tested and confirmed positive via Polymeras chain reaction (PCR). It is currently regarded as the gold standard for COVID-19 testing. The 38 patients were mostly young people below the age of 14 showed mild symptoms during their period of infection. In Wuhan China where the COVID-19 was first reported, a report was made of four medical workers who had 3 consecutive positive PCR tests after recovery. Just as the study in Shenzhen, the patients were asymptomatic and their family members not infected (Leung, 2020). A 40-year old COVID-19 patient who had the RT-PCR examination for SARS-COV-2 performed on her in day 10, 11, and 14 of admission tested negative to all the 3 tests and was discharged although asked to be on quarantine at home. On day 24, the patient was subjected to another test for SARS-CoV-2 having presented pain in the chest and production of cough and sputum. Surprisingly, the test turned out positive hence resulting in the patient being readmitted in Taiwan hospital hence the result showed absorption of lung disease (Zhou et al., 2020).

Studies also reported cases in Japan of a woman who tested positive of COVID-19 the second time after been treated snd discharched from COVID-19 infection, and another study in China also reported some numerous Chinese patients who tested positive after been discharged from the isolation centers (Cheng, 2020; Tie, 2020). On a good note according to the authors, such patients were not found to be infectious. The authors posited that the convalescing COVID-19 patients may not have built enough antibodies or immunity to SARS-CoV-2 and thus become infected again. It could also be that the virus is biphasic like anthrax which entails the virus lying dormant before developing new symptoms. In China, some first cases of re-infection were attributed to discrepancies in testing. For instance, some hospitals tested samples from noses and throats before patients were discharged only to discover the virus in the lower respiratory tracts of the patients on re-infection. This means that patients may remain carriers despite meeting discharged criteria (Stanway \& Kelland, 2020).

Allen Cheng, a professor of infectious disease proclaimed that the details of the Japan cases put to rest the argument of whether the recovered patients tested positive to COVID-19 as a result of them being persistently positive on the disappearance of symptoms or that the patients have been re-infected. It was conclusively put that the patients had been re-infected (Cheng, 2020). One good sign according to Song Tie on China disease control remains that none of the patients appeared to have infected other people after discharge. In other words, it means that the re-infected patient may not be contagious. It could also mean those specific antibodies developed by convalescing patients make them immune to the virus which infected them. However, the infectious disease specialist observed that the second re-infection is mostly non-severe (Tie, 2020). A new study in China revealed that recovered patients usually have very low or even insignificant levels of antibodies to fight the virus. The study showed that a third of recovered patients in China had low levels of antibodies with only ten of the patients having no detectable antibody to neutralize the virus. This raises a lot of concern because when the recovered patients fail to develop high-level immunity to ward off re-infection, it could adversely affect herd immunity needed to stop the wider spread. This implies difficulty in the development of a vaccine. When the real virus could not trigger an antibody response, then what role and use would a weakened version normally used in making vaccines be? (Nisar $\mathrm{ul}, 2020$ ). The WHO nevertheless, is investigating more reports of re-infection among recovered patients (Nebehay, 2020). However, Table 1, 2 shows Symptoms of COVID-19 and how it attacks the Lungs. 
Table 1. Symptoms of COVID-19

\begin{tabular}{|c|c|c|c|}
\hline Symptoms & COVID-19 & Influenza (Flu) & Cold \\
\hline Dry Cough & +++ & +++ & + \\
\hline Fever & +++ & +++ & - \\
\hline Stuffy nose & - & ++ & +++ \\
\hline Sore Throat & ++ & ++ & +++ \\
\hline Shortness of Breath & ++ & -- & -- \\
\hline Headache & ++ & +++ & - \\
\hline Body Aches & ++ & +++ & +++ \\
\hline Sneezing & -- & -- & +++ \\
\hline Exhaustion & ++ & +++ & ++ \\
\hline Diarrhea & - & ++ & -- \\
\hline
\end{tabular}

+++Frequent; ++Sometimes; +Occasionally; -Rare; --Not Observed.

Source: WHO, CDC, in Freund 2020.

Table 2. Shows Effect of COVID-19 to the Lungs

\begin{tabular}{|c|c|c|c|c|c|}
\hline \multicolumn{6}{|c|}{ Effect of COVID-19 to the Lungs } \\
\hline Site of Symptom & Manifestation & Confirmative Test & $\begin{array}{l}\text { Presence of } \\
\text { Viral Nucleic } \\
\text { Acid }\end{array}$ & $\begin{array}{l}\text { Presence of } \\
\text { ACE-2 } \\
\text { Receptor }\end{array}$ & Remarks \\
\hline Pulmonary Lobe & $\begin{array}{l}\text { Bilateral Pneumonia, } \\
\text { Unilateral } \\
\text { pneumonia, }\end{array}$ & CT Scan & Lung sputum & $\begin{array}{l}\text { Transient } \\
\text { secretory cells }\end{array}$ & $\begin{array}{l}\text { Damage of walls } \\
\text { and lining cells by } \\
\text { SARS-CoV-2 }\end{array}$ \\
\hline $\begin{array}{l}\text { Pulmonary } \\
\text { nodules }\end{array}$ & $\begin{array}{lr}\text { Ground } & \text { glass } \\
\text { opacities, } & \text { Irregular } \\
\text { lesions } & \end{array}$ & & & & $\begin{array}{l}\text { Implammasome } \\
\text { pathway mediated } \\
\text { lung injury and } \\
\text { damage }\end{array}$ \\
\hline $\begin{array}{l}\text { Bronchovascular } \\
\text { bundles }\end{array}$ & Thickening & & & & \\
\hline Alveolus & $\begin{array}{l}\text { Shortnessof breath } \\
\text { ARDS }\end{array}$ & Physical Symptom & & & \\
\hline
\end{tabular}

Source: (Cao et al 2020; Han et al 2020) in Balachandar et al (2020).

\section{Reasons for COVID-19 Re-Infection among Recovered Patients}

Numerous reasons have been availed for the positive test results of recovered patients. It could be that virus load gets detected around 10 weeks of onset of covid-19 about the time some of the patients are discharged. It could also be that SARS-CoV2 sheds from its victims for a prolonged time. Also, since the viral load in a sample seems to be fluctuating during disease course, there may be high tendency for a negative result of COVID-19 test even after treatment (Hancocks, Seo, \& Hollingsworth, 2020). Another reason as reviewed could be that the convalescing COVID -19 patients may not have built enough anti bodies or built up immunity to SARS-CoV-2 and thus become infected again. It could also be that the virus is biphasic like anthrax which entails the virus lying dormant before developing new symptoms (Zhou et al., 2020). Be it as it may, it is still unclear whether the second positive result of a treated COVID-19 patient can be linked to transmission of the infection to other persons. However, given to the disastrous outcome of imminent disease transmission, longer observation period ought to be taken into consideration for COVID-19 patients (Zhou et al., 2020).

On the other hand, the presence of severe acute respiratory syndrome coronavirus 2(SARS-CoV-2) viral RNA in a respiratory specimen may not be directly taken as a possibility or probability for disease infection or transmission. 
In the words of the authors, it is a known fact that even after infection with some of the past viral diseases like Ebola virus, Middle East respiratory syndrome, Coronavirus, Zika virus, Influenza virus and Measles virus, that the viral RNA can still be seen long after the disappearance of the virus. For instance, the measles virus can still be seen 6-8 weeks even after clearance of the infectious virus. During the period, the immune system usually tries to neutralize viruses by envelop lysing or by bringing together (aggregating) the particles of the virus. The efforts are always in the bid to avoid or prevent re-infection. However, the RNA does not become eliminated. It rather gets degraded gradually and slowly over a period of time. Be that as it may, making use of sensitive PCR methods can offer value in diagnosing cases but caution should be observed as the PCR does not differentiate infectious virus from non infectious nucleic acid (Atkinson \& Petersen, 2020). The study warned against the use of findings of their study in making conclusions about prolonged shedding of virus or even using their findings to make or amend policies on isolation hence more research or data on viral load is needed.

From the reviews, it can easily be summarized that it is a reality on ground that recovered patients can be re-infected. Other people may not be infected by a recovered re-infected patient. On re-infection, the symptoms may appear mild or less severe than the first infection period. Antibodies are not in sufficient levels (detectable levels) or may even be unavailable at recovery. The re-infections as reviewed happen between 10 days and 2 weeks on recovery.

\section{Lacuna in the Review vis-à-vis PCR Test Results}

The studies (Atkinson \& Petersen 2020), who observed that the PCR does not differentiate infectious virus RNA from non infectious Virus RNA invariably contradicts the popular perception that re-infected patients cannot infect other people. The infectious virus RNA as the name depicts may infect others. This earnestly calls for a more in-depth study that will determine whether the infectious RNA can actually be contagious and capable of infecting others. This will avert further transmission of the virus from those already assumed to have fully recovered.

\subsection{COVID-19 Re-Infection and Patient's Lung Health}

The Lung is a vital organ of the body playing great roles in respiration, circulation, excretion and speech production in humans (Sampson, 2018). Any cause depriving the lungs from performing these functions has affected lung health. Lung health in the context of this paper means the lung being in a complete stable and disease free. Any damage to the lungs as a result of infection or re-infection has affected virtually every biological functioning of the body that may lead to eventual death. It is a known fact that COVID-19 leaves patient with severe lung problems. When the patient is re-infected, how is the secondary effect on lungs? Does it imply further damage to the lungs since it also comes with symptoms although mild in nature as pointed out from the reviewed studies? Answering these questions will be of significance to WHO, various countries' Centers for disease control, medical personnel and health policy makers. It will help them to develop and establish the quickest means and channel of treating the new re-infected cases so as to avert further fatal lung damage or death arising from complications experienced by already assumed recovered patients. The most convenient duration at most for a patient to be discharged can be unveiled when the generated questions are answered. It will definitely bring to a halt, the current norm of some recovered patients going home only to return few days after with COVID-19 re-infection symptoms. It will also bring to the barest minimum lung incapacity and irredeemable damage caused by re-infection.

\subsection{Effects of COVID-19 on the Lungs of Re-Infected Patients: Implication for Lung health}

When the lungs become filled with inflammatory material during COVID-19 infection, they can no longer get sufficient oxygen to the blood stream thus reducing the body's ability to take oxygen around the body and getting rid of carbon dioxide. It is the most cause of death due to severe pneumonia. Also when the virus reaches the lungs, the mucous membranes are inflamed leading to damage on the alveoli or lung sacs. They in turn try to work harder in order to carry out their oxygen supply function to the rest of the body parts and also removing carbon dioxide from the blood as to be exhaled. The swelling of liver lymph nodes caused by the virus can impair oxygen flow. It can also cause the lung areas to be filled with pus apart from fluid and dead cells hence the occurrence of pneumonia which is infection of the lung. In worst cases known as acute respiratory distress syndrome, the lungs may be so filled with much fluid that no amount of life support may be of help and the patient dies (Readfern, 2020; Belluk, 2020).

From the review, it implies that the virus reaching the lungs at any point in time does not say well for the lung's health whether first time infection or on re-infection. A lung infection mild or severe impedes normal breathing pattern and affects almost all vital body functioning waste management inclusive (Bradford, 2018). In either mild or severe lung infection, a prompt medical aid is needed to avert imminent mortality. The review has also pointed 
out that during re-infection of the lungs that may have been caused by re-infection with COVID-19, other parts of the body may first be infected before the lungs implying urgent medical attention on those parts before the Lungs can be reached. A lung infection with coronavirus may also lead to infection of other cells such as the gastro intestinal system which explains the symptoms of diarrhea or indigestion in some patients. Studies have observed that at a re-infected COVID-19 patient may end up with reduced lung capacity and function following bouts of the disease (Healy, 2020; McFall-Johnsen, 2020; Freund, 2020; Pawlowski, 2020). It was discovered by a Hongkong hospital Authority that 2 or 3 recovering patients had lost $20-30 \%$ of lung function.

\section{Conclusion}

Based on the reviews, there have been cases of re-infection among recovered patients. The symptoms are the same as the first instance although less severe. Regardless of the mild symptoms on re-infection, the lungs may be invaded once more and sometimes left incapacitated or completely damaged. Lung health being a sinequanon for human existence, prompt medical attention ought to be quickly availed when patients present re-infection by COVID-19. Based on this the paper recommended that:

1) WHO in collaboration with $\mathrm{CDC}$ of different nations and health policy makers should make quick health policies backed by law, mandating every recovered patient from COVID-19 to be in hospital custody for at least two weeks upon discharge. This will also make for easy and early detection of re-infection and afford the patient access to ventilators and other equipment for enhancement of lung health.

2) The Government at all levels should organize periodic free Lung function tests for recovered Corona virus patients for early detection and treatment of any ailing lung.

3) Health Sectors should collaborate with Manufacturers to produce and make free distribution of small and more portable ventilators for every COVID-19 Patient whether recovered or still infected for proper management of lung health.

4) Proper health education should be availed to the recovered patients to avoid any exposures or habbits (different from the index disease) such as smoking that can pose dangers to the already fatigued lungs

\section{Acknowledgements}

None to declare.

\section{Funding}

This research received no external funding.

\section{Competing Interests Statement}

The authors declare that there are no competing or potential conflicts of interest.

\section{References}

Atkinson, B., \& Petersen, E. (2020). SARS-CoV-2 shedding and infectivity. The Lancet. https://doi.org/10.1016/S0140-6736(20)30868-0

Balachandar, V., Mahalaxmi, I., Subramaniam, M., Kaavya, J., Kumar, S. K., Laldinmawii, G., ... \& Cho, S.G. (2020). Follow-up studies in COVID-19 recovered patients - is it mandatory?. Science of the Total Environment, 729, 139021. PMID: 32360909; PMCID: $\quad$ PMC7184970. https://doi.org/10.1016/j.scitotenv.2020.139021

Belluk, P. (2020). What does the corona virus do to the body?. Retrieved 19th April 2020 from nytimes.co.-com.cdc.ampproject.Org

Bradford, A. (2018). Lungs: facts, function and diseases. Retrieved 20th of April, 2020 from www-livescience-com.cdn.ampproject

Cao Y., Liu X., Xiong, L., \& Cai, K. (2020). Imaging and clinical features of patients with 2019 novel coronavirus SARS-CoV-2: a systematic review and meta-analysis. Journal of Medical Virology. https://doi.org/10.1002/jmv.25822

Cheng, A. (2020). Concerns as Covid-19 reappears in discharged patients worldwide. New Straits Times: New Straits Times Press (M) Bhd.

European Centre for Disease Prevention and Control. (2020). An agency of the European Union. Situation update worldwide, as of 1 May 2020.

Freund, A. (2020). COVID-19: recovered patients have partially reduced lung function. Doc's association Kashmir 
urges immune testing for recovered patients. Asian Web News. Retrieved April 19th, 2020 from www.dw.com>COVID-19.

Han, X., Fan, Y., Wan, Y. L., \& Shi, H. (2020). A diabetic patient with 2019-nCoV (COVID-19) infection who recovered and was discharged from hospital. Journal of Thoracic Imaging. https://doi.org/10.1097/RTI.0000000000000506

Hancocks, P., Seo, Y., \& Hollingsworth, J. (2020). Recovered coronavirus patients are testing positive again. Can you get reinfected? Cable News Network Turner Broadcasting System, Inc.

Healy, M. (2020). Coronavirus may cause lasting damage throughout the body, doctors fear. Retrieved from www.jpost.com/

Leung, H. (2020). Can you be re-infected after recovering from Corona virus? Here's what we know about covid-19 immunity. Retrieved 18th April, 2020 from www.https://time.com

Levithan, R. (2020). The infection that's silently killing Corora virus Patients. Retrieved 20th April, 2020 from www.nytimes.com

McFall-Johnsen, M. (2020). More than 370, 000 people have recovered from COVID-19. Here's what we know about the Survivors. Retrieved April 19th, 2020 from www.businessinsider.com

Nebehay, S. (2020). WHO is investigating reports of recovered COVID-19 patients testing positive again. WHO. Retrived 19th April, 2020 from https://www.reuters.com

Nisarul, H. (2020). Patients who recover are getting infected with the virus again. Asian web news on covid-19. Srinagar, Accessed from www.AsianLiveUpdates.com

Pawlowski, A. (2020). What are the big-term health consequences of COVID-19?. Retrieved April 19th, 2020 from www.today.com>health

Readfern, G. (2020). What happens to people's lungs whey they get corona virus?, The Guadian. Retrieved 19thApril, 2020 from www.theguardian.com

Sampson, S. (2018). What do the lungs do?. Retrieved 20th April, 2020 from www.medicalnewstoday.com

Stanway, D., \& Kelland, K. (2020). Explainer: Coronavirus reappears in discharged patients, raising questions in containment fight. Coronavirus Bulletin 2020.

Tie, S. (2020). Discharged patients test positive again The Star. Retrieved February 28, 2020 from www.thestar.com.my

Zhou, M., Li, Q., Cao, L., Liu, Y., Zha, Y., Xie, H., Zeng, M., ... \& Zeng, Y. (2020). Re-emergence of SARS-CoV2 in a discharged COVID-19 case. Journal of Microbiology, Immunology and Infection. https://doi.org/10.1016/j.jmii.2020.03.031

\section{Copyrights}

Copyright for this article is retained by the author(s), with first publication rights granted to the journal.

This is an open-access article distributed under the terms and conditions of the Creative Commons Attribution license (http://creativecommons.org/licenses/by/4.0/). 